\title{
Endothelin antagonism for patients with chronic kidney disease: still a hope for the future
}

\author{
Markus P. Schneider ${ }^{1}$ and Johannes F. Mann ${ }^{1,2}$ \\ ${ }^{1}$ Department of Nephrology and Hypertension, University of Erlangen-Nuremberg and Nuremberg General Hospital, Erlangen, Germany and \\ ${ }^{2}$ Department of Nephrology, Hypertension \& Rheumatology, Munich General Hospitals, Munich, Germany
}

Correspondence and offprint requests to: Markus P. Schneider; E-mail: markus.schneider@uk-erlangen.de

\section{ABSTRACT}

Endothelin is tightly involved in the regulation of vascular and renal function in health and in disease. In a variety of animal models of kidney disease, endothelin promotes renal injury through effects on inflammation and fibrosis. Furthermore, experimental data strongly suggest that blocking the actions of endothelin should be beneficial in patients with chronic kidney disease. However, despite encouraging pre-clinical and clinical evidence, endothelin antagonists are not yet an established treatment option in patients with chronic kidney disease. This article reviews key physiological and pathophysiological aspects of the endothelin system in the vasculature and the kidney, as well as results of pre-clinical and clinical studies on the use of endothelin antagonists in chronic kidney disease. We will also provide an outlook on the future of endothelin antagonism in this area, and issues to be resolved before endothelin antagonists are to become a reality for patients with chronic kidney disease.

\section{INTRODUCTION}

More than 20 years ago, Yanagisawa et al. [1] discovered endothelin, the most powerful vasoconstrictor substance known in humans. In addition to its role in cardiovascular biology, the involvement of endothelin in many other physiological systems, which, to name a few, includes the nervous, the immune and the reproductive systems, has been firmly established. Endothelin is also involved in regulating the structure and function of the kidney, and experimental data strongly suggest that blocking the actions of endothelin might be beneficial in patients with chronic kidney disease (CKD). However, despite encouraging pre-clinical and clinical evidence, endothelin antagonists are not yet an established treatment option in patients with CKD. So far, approved clinical indications for endothelin antagonists are only pulmonary arterial hypertension and scleroderma-related digital ulcers. This article reviews key physiological and pathophysiological aspects of the endothelin systems as relevant for CKD, as well as results of pre-clinical and clinical studies on the use of endothelin antagonists in CKD. We will also provide an outlook on the future of endothelin antagonism in CKD, and issues to be resolved before endothelin antagonists are to become a reality for patients with $\mathrm{CKD}$.

\section{PHYSIOLOGY OF THE VASCULAR}

\section{ENDOTHELIN SYSTEM}

Encoded by separate genes, the human endothelin family encompasses three 21-amino-acid long isopeptides, endothelin-1, endothelin-2 and endothelin-3 (ET-1, ET-2 and ET-3) [2]. In the cardiovascular and renal systems, the most extensively studied and most important isoform is ET-1. Endothelial cells are the major source of ET-1 in the vasculature (Figure 1). There are two types of receptors for endothelins: the endothelin type $\mathrm{A}\left(\mathrm{ET}_{\mathrm{A}}\right)$ and the endothelin type $\mathrm{B}\left(\mathrm{ET}_{\mathrm{B}}\right)$ receptor. Both $\mathrm{ET}_{\mathrm{A}}$ and $\mathrm{ET}_{\mathrm{B}}$ receptors, located on vascular smooth muscle cells, mediate strong and long-lasting vasoconstrictor responses to ET-1. The $\mathrm{ET}_{\mathrm{B}}$ receptor, however, has two additional functions that tend to oppose the vasoconstrictor effects of ET-1. Activation of $\mathrm{ET}_{\mathrm{B}}$ receptors on endothelial cells causes release of prostaglandins and nitric oxide, resulting in relaxation of the underlying smooth muscle cells. Further, endothelial $\mathrm{ET}_{\mathrm{B}}$ receptors are important for clearing ET-1 from the circulation, thus limiting the vasoconstrictor activity of ET-1 (for a detailed discussion of the various roles of the $\mathrm{ET}_{\mathrm{A}}$ and $\mathrm{ET}_{\mathrm{B}}$ receptors, please see review [3]). In mice, endothelial-cell specific disruption of the ET-1 gene reduces blood pressure (BP), providing genetic evidence for an essential role of endothelium-derived ET-1 in the maintenance of basal vascular tone and BP, with an overall BP-increasing effect [4]. This is also the case in humans, as the overall effect of ET-1 


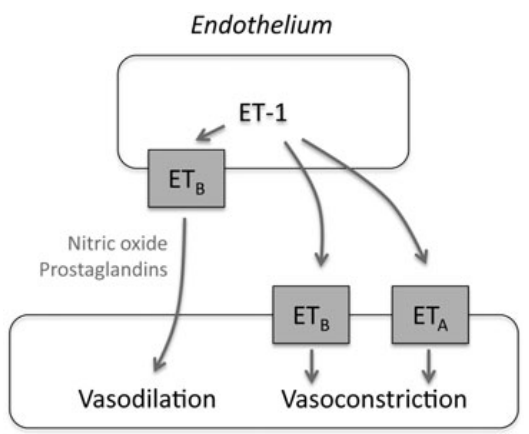

Vascular smooth muscle

F I G U RE 1: The endothelin system in the vasculature.

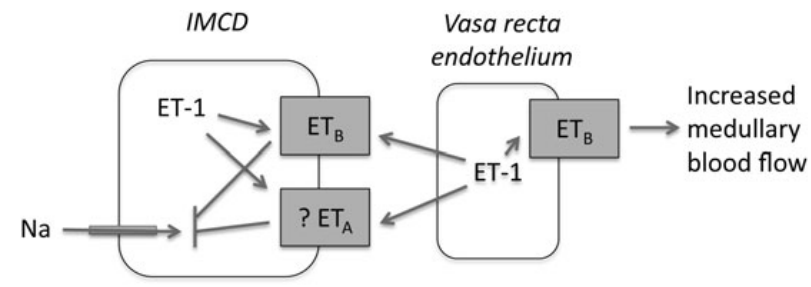

F I G U R E 2: The endothelin system in the kidney (inner renal medulla).

generated in the human vasculature is vasoconstriction [5]. In addition to the regulation of vascular tone, ET- 1 also has growth-promoting effects on vascular smooth muscle cells.

PHYSIOLOGY OF THE RENAL ENDOTHELIN SYSTEM

In the kidney, the inner renal medulla, and in particular the principal cells of the inner medullary collecting duct (IMCD), produces the greatest amounts of ET-1 (Figure 2). Both $\mathrm{ET}_{\mathrm{A}}$ and $\mathrm{ET}_{\mathrm{B}}$ receptors are expressed in this region $[6,7]$. Collecting duct cells express $\mathrm{ET}_{\mathrm{A}}$ and $\mathrm{ET}_{\mathrm{B}}$ receptors, pericytes of the vasa recta and smooth muscle cells of the more upstream afferent arterioles $\mathrm{ET}_{\mathrm{A}}$ and $\mathrm{ET}_{\mathrm{B}}$ receptors [8], and endothelial cells of the vasa recta and affererent arterioles $\mathrm{ET}_{\mathrm{B}}$ receptors. Mice with collecting duct-specific deletion of ET-1 were found to have salt-sensitive hypertension, demonstrating the importance of ET-1 within this particular nephron segment for fluid balance and BP control $[9,10]$. A further series of experiments with cell-specific deletions of the receptors showed that it mainly the $\mathrm{ET}_{\mathrm{B}}$ receptor on collecting duct cells that, in an autocrine fashion, mediates the natriuretic and antihypertensive effects of collecting duct-derived ET-1 [11-13]. Counteracting the vasoconstrictor actions of smooth muscle $\mathrm{ET}_{\mathrm{A}}$ and $\mathrm{ET}_{\mathrm{B}}$ receptors $[8,14], \mathrm{ET}_{\mathrm{B}}$ receptors on endothelial cells of afferent arterioles and the vasa recta contribute to the natriuretic and antihypertensive effects of ET-1 by triggering vasodilation and an increase in blood flow into the renal medulla. Increased medullary perfusion raises peritubular hydrostatic pressure and causes a reduction in the tonicity within the interstitium of the renal medulla. These, in turn, result in a decrease of sodium reabsorption along the nephron. Interestingly, overall activation of $\mathrm{ET}_{\mathrm{B}}$ receptors elicits afferent arteriolar constriction of juxtamedullary nephrons in rats during a normal salt intake, but dilation during a high salt intake $[14,15]$. These findings suggest that endothelial $\mathrm{ET}_{\mathrm{B}}$ receptors and preservation of medullary blood flow are antihypertensive mechanisms during high sodium diets. ET-1 has also been shown to inhibit sodium reabsorption in the thick ascending limb via actions through the $\mathrm{ET}_{\mathrm{B}}$ receptor, which may contribute to the overall diuretic effects of ET-1 in the kidney $[16,17]$.

There is more recent evidence that under specific circumstances, $\mathrm{ET}_{\mathrm{A}}$ receptors may also participate in the natriuretic and antihypertensive effects of renal medullary ET-1. Nephron-specific deletion of $\mathrm{ET}_{\mathrm{A}}$ receptors in mice causes mild volume expansion under a high salt intake without a change of $\mathrm{BP}$ [18]. In female rats, $\mathrm{ET}_{\mathrm{A}}$ receptors within the renal medulla contribute to ET-1-induced natriuresis by a nitric oxide synthase 1 (nNOS)-dependent mechanism, an effect that is abolished by ovarectomy [19]. Finally, there is recent evidence that ET-1 inhibits sodium reabsorption through both $\mathrm{ET}_{\mathrm{A}}$ and $\mathrm{ET}_{\mathrm{B}}$ receptors in the cortical collecting duct [20]. Therefore, summarizing the experimental data on the roles of the renal $\mathrm{ET}_{\mathrm{A}}$ and $\mathrm{ET}_{\mathrm{B}}$ receptors for renal sodium excretion, the activation of renal $\mathrm{ET}_{\mathrm{B}}$ receptors clearly favours sodium excretion and thus contributes to a lower BP. The role of renal $\mathrm{ET}_{\mathrm{A}}$ receptor is less clear, but recent experimental evidence suggests that the activation of those receptors may as well favour natriuresis, at least under specific circumstances.

\section{PATHOPHYSIOLOGY OF THE ENDOTHELIN} SYSTEM IN CKD

Alterations in the function and structure of mesangial cells and podycytes play an important pathogenetic role in the progression of renal diseases. Human mesangial cells and podocytes express functionally active endothelin receptors as they bind ET-1, which subsequently causes a rapid increase in intracellular calcium levels [21]. Thus, ET-1 significantly affects signal transduction and proliferation of mesangial cells and podocytes. There is also strong evidence that the activation of the endothelin system directly promotes renal fibrosis, as rats with transgenic overexpression of ET-1 develop severe glomerulosclerosis and interstial fibrosis [22]. Cell culture studies have further shown that exposure to protein overload, as a general model of proteinuric nephropathies, and exposure to shigatoxin, as a model for the haemolytic uraemic syndrome, both upregulate ET-1 expression in cultured podocytes $[23,24]$. The release of ET-1 then results in further deterioration of podocyte structure and function by an autocrine mechanism [23]. Experimental evidence for involvement of the endothelin system is particularly strong in diabetic kidney disease, as $\mathrm{ET}-1$, the $\mathrm{ET}_{\mathrm{A}}$ and $\mathrm{ET}_{\mathrm{B}}$ receptors are strongly overexpressed in the renal cortex of rats with streptozotocininduced diabetes [25].

In humans, there are only few data on the expression of the components of the endothelin system in patients with 
kidney disease. For example, an increased expression of ET-1 has been found in kidneys of patients with IgA nephropathy $[26,27]$. Some studies further suggest that urinary ET-1 levels may be a useful marker of renal injury $[28,29]$. There is also some evidence from human studies that the $\mathrm{ET}_{\mathrm{A}}$ receptor, and perhaps also the activation of the $\mathrm{ET}_{\mathrm{B}}$ receptor, contribute to the progression of atherosclerosis, which is a significant clinical complication of CKD [30, 31].

\section{EXPERIMENTAL STUDIES WITH}

\section{ENDOTHELIN ANTAGONISTS}

There is abundant evidence from experimental studies for the beneficial effects of endothelin antagonism in non-diabetic and diabetic models of renal disease. Ortmann et al. [32] have shown that 4-week oral treatment with the $\mathrm{ET}_{\mathrm{A}}$ receptor selective antagonist darusentan partially reverses ageing-associated glomerulosclerosis in rats. Further experiments from that study demonstrated that the structural damage to podocytes induced by puromycin aminonucleoside, as a model of focal segmental glomerulosclerosis, is attenuated by $\mathrm{ET}_{\mathrm{A}}$ receptor, but not $\mathrm{ET}_{\mathrm{B}}$ receptor, blockade [32]. In the shigatoxin-induced model of the haemolytic uraemic syndrome, $\mathrm{ET}_{\mathrm{A}}$ receptor blockade was able to prevent the pathological changes of the podocyte cytoskeleton [24]. Together, these studies support the concept that the activation of the endothelin system can contribute to renal disease progression, mediated partly via actions on podocytes.

Experimental data on whether selective $\mathrm{ET}_{\mathrm{A}}$ receptor blockade should be prefered over non-selective $\mathrm{ET}_{\mathrm{A}} / \mathrm{ET}_{\mathrm{B}}$ receptor blockade for preventing progressive renal disease are not entirely consistent. In models of non-diabetic renal disease, some studies, such as in the ageing-associated glomerulosclerosis model, suggest that $\mathrm{ET}_{\mathrm{A}}$ selective blockade is more effective than non-selective $\mathrm{ET}_{\mathrm{A}} / \mathrm{ET}_{\mathrm{B}}$ receptor blockade, whereas others, such as studies in the renal mass reduction model, suggest that treatment with both types of blockers are equally effective in protecting from disease progression $[33,34]$.

In the streptozotocin model of diabetes, selective $\mathrm{ET}_{\mathrm{A}}$ receptor blockade has been shown to reduce albuminuria, extracellular matrix production and glomerular inflammation [35, 36]. Further studies have shown that selective $\mathrm{ET}_{\mathrm{A}}$ receptor and non-selective $\mathrm{ET}_{\mathrm{A}} / \mathrm{ET}_{\mathrm{B}}$ receptor blockade both reduce albuminuria and glomerular permeability, but only selective $\mathrm{ET}_{\mathrm{A}}$ receptor blockade reduces glomerular inflammation [37]. Thus, selective $\mathrm{ET}_{\mathrm{A}}$ receptor blockade may be preferable for treatment of diabetic kidney disease. Of note, in uninephrectomized rats with streptozotocin-induced diabetes, regression of glomerular and interstitial injury was achieved by $\mathrm{ET}_{\mathrm{A}}$ receptor blockade with avosentan combined with renin-angiotensin system inhibition with lisinopril, whereas each drug alone was only able to attenuate glomerular and interstitial injury, suggesting synergistic effects of combining the two treatment principles [38]. Chronic $\mathrm{ET}_{\mathrm{A}}$ receptor blockade has further been shown to normalize endothelial function and reduce atheroma formation in a mouse model of atherosclerosis, which, as alluded to earlier, presents a significant comorbidity in CKD [39].
CLINICAL STUDIES WITH ENDOTHELIN ANTAGONISTS

There was some evidence from early clinical experimental studies that the contribution of endothelins to vascular tone of the forearm vasculature is reduced (rather than increased) in patients with advanced CKD compared with healthy controls [40, 41]. Nonetheless, Goddard et al. [42] demonstrated that the $\mathrm{ET}_{\mathrm{A}}$ selective antagonist BQ-123 significantly reduces $\mathrm{BP}$ and increases renal blood flow in hypertensive patients with non-diabetic CKD. In the same study, combined $\mathrm{ET}_{\mathrm{A}} / \mathrm{ET}_{\mathrm{B}}$ receptor blockade also reduced $\mathrm{BP}$, but was not able to increase renal blood flow. The renal haemodynamic effects of selective $\mathrm{ET}_{\mathrm{A}}$ receptor blockade were similar to those commonly associated with renin-angiotensin system inhibition in that a reduction of filtration fraction was observed, perhaps suggesting similar renal protection in the long term [42]. Subsequent studies showed that $\mathrm{ET}_{\mathrm{A}}$ receptor blockade with i.v. BQ-123 combined with reninangiotensin system inhibition even had synergistic renal haemodynamic effects and together were able to increase sodium excretion significantly [43]. These synergistic effects were abolished with $\mathrm{ET}_{\mathrm{B}}$ receptor blockade or with $\mathrm{nNOS}$ inhibition, suggesting that the beneficial effects of $\mathrm{ET}_{\mathrm{A}}$ blockade were mediated via activation of the $\mathrm{ET}_{\mathrm{B}}$ receptor. By way of mechanism, blockade of the $\mathrm{ET}_{\mathrm{A}}$ receptor appears to leave more ET-1 available for activation of the $\mathrm{ET}_{\mathrm{B}}$ receptor, i.e. ET-1 is shifted to activate more $\mathrm{ET}_{\mathrm{B}}$ receptors [43]. Further, studies by Dhaun et al. [44] demonstrated that acute $\mathrm{ET}_{\mathrm{A}}$ receptor blockade with $\mathrm{i}$. v. BQ-123 reduces $\mathrm{BP}$, arterial stiffness and proteinuria in patients with non-diabetic kidney disease. While the reduction in $\mathrm{BP}$ and the increase in renal blood flow were similar to the calcium channel blocker nifedipine-as a control-in comparison with BQ-123, there was a substantially greater reduction in arterial stiffness and proteinuria with BQ-123, suggesting BP-independent effects of $\mathrm{ET}_{\mathrm{A}}$ receptor blockade.

In line with these acute effects $\mathrm{ET}_{\mathrm{A}}$ receptor blockade, 6 weeks oral treatment with the sulphonamide-based, highly $\mathrm{ET}_{\mathrm{A}}$ receptor selective antagonist sitaxentan reduced proteinuria more than oral treatment with nifedipine, despite similar reductions in BP [45]. Only sitaxentan reduced filtration fraction, suggesting that the disparate effects on proteinuria may at least in part be explained by differences in the renal haemodynamic effects of these two drugs. Interestingly, no cases of clinically significant oedema were reported with sitaxentan, which is highly selective for the $\mathrm{ET}_{\mathrm{A}}$ receptor $\left(>1000: 1 \mathrm{ET}_{\mathrm{A}}: \mathrm{ET}_{\mathrm{B}}\right.$ binding selectivity). Sitaxentan was approved for the treatment of pulmonary arterial hypertension in 2006. Increases in liver enzymes are relatively common with this and other endothelin antagonists (up to $\approx 10 \%$ of patients [46]). Unfortunately, several cases of fatal liver failure were reported with sitaxentan in the following years, and the drug was withdrawn from the market in 2010. It has been postulated that some endothelin antagonists, in particular bosentan and sitaxentan [47], cause hepatitis by inhibition of bile salt transporter pumps, but immune-mediated or idiosyncratic mechanisms are also possible.

Clinical trials in patients with type 2 diabetes and nephropathy have also been conducted with avosentan, a 
sulphonamide-based, non-selective $\mathrm{ET}_{\mathrm{A}} / \mathrm{ET}_{\mathrm{B}}$ receptor antagonist (50:1 $\mathrm{ET}_{\mathrm{A}}: \mathrm{ET}_{\mathrm{B}}$ binding selectivity). An initial dosefinding study in 286 obese patients with diabetic nephropathy and relatively preserved kidney function (average estimated glomerular filtration rate of $80 \mathrm{~mL} / \mathrm{min}$ ) found substantial reductions in albuminuria by $\sim 20-40 \%$, again 'on top' of standard therapy with either an angiotensin-converting enzyme (ACE) inhibitor or an angiotensin receptor blocker [48]. In the phase 3 trial that followed (ASCEND), patients with more advanced diabetic nephropathy were included (an average estimated glomerular filtration rate of $33 \mathrm{~mL} / \mathrm{min}$ ). Again, avosentan led to substantial reductions in albumuria but the trial had to be terminated prematurely in 2007 as numerous patients suffered drug-related side effects including the development of severe heart failure, and there was a trend towards more deaths in the active treatment groups [49]. Most experts agree that heart failure is the consequence of fluid retention due to renal sodium retention, in particular with those endothelin antagonists that are less $\mathrm{ET}_{\mathrm{A}}$ receptor selective.

Darusentan, a propanoic acid-based $\mathrm{ET}_{\mathrm{A}}$ selective antagonist was studied in patients with resistant arterial hypertension, i.e. patients with arterial hypertension in which BP was not controlled by three antihypertensives including a diuretic. In a first dose-ranging study in 115 patients, adding darusentan lowered BP substantially [50]. In the second, larger study in 379 patients (DORADO), data on albuminuria were also presented. In addition to lowering BP, darusentan reduced urinary albumin excretion in those with proteinuric hypertensive nephropathy. Most frequent side effects were fluid retention and headaches. Unfortunately, despite these overall encouraging results and the potential of this drug in patients with proteinuric kidney disease, further development of darusentan was abandoned in December 2009.

Rabelink et al. were the first to report antiproteinuric effects with the non-sulphonamide, highly $\mathrm{ET}_{\mathrm{A}}$ receptor selective antagonist atrasentan in a small exploratory study (1800:1 $\mathrm{ET}_{\mathrm{A}}$ : $\mathrm{ET}_{\mathrm{B}}$ binding selectivity). In 10 patients with type 1 diabetes treated for 12 weeks, potent antiproteinuric effects were seen on top of standard renin-angiotensin system blockade (thesis, University of Utrecht). Kohan et al. [51] have recently confirmed the potent antiproteinuric effects of atrasentan in a larger phase 2 trial in 89 obese patients with type 2 diabetes. A larger phase 3 trial to assess the efficacy of atrasentan in slowing the progression of renal function decline has just started.

Development of endothelin antagonists for patients with CKD has been slowed down by side effects of these drugs, which included oedema formation, heart failure and liver toxicity. Compared with the excellent safety profile of ACE inhibitors and angiotensin receptor blockers, these safety issues are considerable hurdles for pharmaceutical companies. Learning more about the biology of the endothelin system in health and in disease will perhaps make a safer use of these drugs possible in specific clinical conditions. As an example, oedema formation and subsequent heart failure appeared to be more frequent in those trials in which a less $\mathrm{ET}_{\mathrm{A}}$ selective compound was used, which fits well with the experimental data that the renal $\mathrm{ET}_{\mathrm{B}}$ receptor is mainly responsible for natriuresis. Since selectivity is also a matter of dose, using lower doses of $\mathrm{ET}_{\mathrm{A}}$ antagonists together with adequate use of diuretics may also help to overcome oedematous side effects in CKD patients. In terms of liver toxicity, inhibition of hepatobiliary transporters appears to differ significantly between specific endothelin antagonists, and we clearly need to learn more about the precise molecular mechanisms [47]. Of note, endothelin antagonists are teratogenic and will not be an option for women of childbearing potential [52].

In summary, endothelin antagonists have demonstrated impressive antiproteinuric effects in CKD patients, even in those with inhibition of the renin-angiotensin system. Since renin-angiotenin system inhibition can only provide partial protection from renal disease progression, further development of endothelin antagonists for patients with kidney disease still remains a hope for the future.

\section{ACKNOWLEDGEMENT}

J.F.M. is supported by the European Commission (Grant 241544, SysKid).

\section{CONFLICT OF INTEREST STATEMENT}

J.F.M. reports consultant honoraria from Abbott, Acetelion and Novartis.

\section{REFERENCES}

1. Yanagisawa M, Kurihara H, Kimura S et al. A novel potent vasoconstrictor peptide produced by vascular endothelial cells. Nature 1988; 332: 411-415

2. Inoue $\mathrm{A}$, Yanagisawa $\mathrm{M}$, Kimura $\mathrm{S}$ et al. The human endothelin family: three structurally and pharmacologically distinct isopeptides predicted by three separate genes. Proc Natl Acad Sci USA 1989; 86: 2863-2867

3. Schneider MP, Boesen EI, Pollock DM. Contrasting actions of endothelin ET(A) and ET(B) receptors in cardiovascular disease. Annu Rev Pharmacol Toxicol 2007; 47: 731-759

4. Kisanuki YY, Emoto N, Ohuchi T et al. Low blood pressure in endothelial cell-specific endothelin 1 knockout mice. Hypertension 2010; 56: 121-128

5. Haynes WG, Ferro CJ, O'Kane KP et al. Systemic endothelin receptor blockade decreases peripheral vascular resistance and blood pressure in humans. Circulation 1996; 93: 1860-1870

6. Kohan DE. Endothelin synthesis by rabbit renal tubule cells. Am J Physiol 1991; 261: F221-F226

7. Kohan DE, Hughes AK, Perkins SL. Characterization of endothelin receptors in the inner medullary collecting duct of the rat. J Biol Chem 1992; 267: 12336-12340

8. Silldorff EP, Yang S, Pallone TL. Prostaglandin E2 abrogates endothelininduced vasoconstriction in renal outer medullary descending vasa recta of the rat. J Clin Invest 1995; 95: 2734-2740

9. Ahn D, Ge Y, Stricklett PK et al. Collecting duct-specific knockout of endothelin-1 causes hypertension and sodium retention. J Clin Invest 2004; 114: 504-511

10. Schneider MP, Ge Y, Pollock DM et al. Collecting duct-derived endothelin regulates arterial pressure and $\mathrm{Na}$ excretion via nitric oxide. Hypertension 2008; 51: 1605-1610

11. Ge Y, Bagnall A, Stricklett PK et al. Collecting duct-specific knockout of the endothelin B receptor causes hypertension and sodium retention. Am J Physiol Renal Physiol 2006; 291: F1274-F1280 
12. Ge Y, Bagnall A, Stricklett PK et al. Combined knockout of collecting duct endothelin A and B receptors causes hypertension and sodium retention. Am J Physiol Renal Physiol 2008; 295: F1635-F1640

13. Ge Y, Stricklett PK, Hughes AK et al. Collecting duct-specific knockout of the endothelin A receptor alters renal vasopressin responsiveness, but not sodium excretion or blood pressure. Am J Physiol Renal Physiol 2005; 289: F692-F698

14. Inscho EW, Imig JD, Cook AK et al. ETA and ETB receptors differentially modulate afferent and efferent arteriolar responses to endothelin. $\mathrm{Br} \mathrm{J}$ Pharmacol 2005; 146: 1019-1026

15. Schneider MP, Inscho EW, Pollock DM. Attenuated vasoconstrictor responses to endothelin in afferent arterioles during a high-salt diet. Am J Physiol Renal Physiol 2007; 292: F1208-F1214

16. Plato CF, Pollock DM, Garvin JL. Endothelin inhibits thick ascending limb chloride flux via ET(B) receptor-mediated NO release. Am J Physiol Renal Physiol 2000; 279: F326-F333

17. Herrera M, Hong NJ, Ortiz PA et al. Endothelin-1 inhibits thick ascending limb transport via Akt-stimulated nitric oxide production. J Biol Chem 2009; 284: 1454-1460

18. Stuart D, Rees S, Woodward SK et al. Disruption of the endothelin A receptor in the nephron causes mild fluid volume expansion. BMC Nephrol 2012; 13: 166

19. Nakano D, Pollock DM. Contribution of endothelin A receptors in endothelin 1-dependent natriuresis in female rats. Hypertension 2009; 53: 324-330

20. Lynch IJ, Welch AK, Kohan DE et al. Endothelin-1 inhibits sodium reabsorption by ETA and ETB receptors in the mouse cortical collecting duct. Am J Physiol Renal Physiol 2013 May 22. [Epub ahead of print]

21. Rebibou JM, He CJ, Delarue F et al. Functional endothelin 1 receptors on human glomerular podocytes and mesangial cells. Nephrol Dial Transplant 1992; 7: 288-292

22. Hocher B, Thone-Reineke C, Rohmeiss $P$ et al. Endothelin-1 transgenic mice develop glomerulosclerosis, interstitial fibrosis, and renal cysts but not hypertension. J Clin Invest 1997; 99: 1380-1389

23. Morigi M, Buelli S, Angioletti S et al. In response to protein load podocytes reorganize cytoskeleton and modulate endothelin-1 gene: implication for permselective dysfunction of chronic nephropathies. Am J Pathol 2005; 166: 1309-1320

24. Morigi M, Buelli S, Zanchi C et al. Shigatoxin-induced endothelin-1 expression in cultured podocytes autocrinally mediates actin remodeling. Am J Pathol 2006; 169: 1965-1975

25. Minchenko AG, Stevens MJ, White L et al. Diabetes-induced overexpression of endothelin-1 and endothelin receptors in the rat renal cortex is mediated via poly(ADP-ribose) polymerase activation. FASEB J 2003; 17: 1514-1516

26. Rastaldi MP, Tunesi S, Ferrario F et al. Transforming growth factor-beta, endothelin-1, and c-fos expression in necrotizing/crescentic IgA glomerulonephritis. Nephrol Dial Transplant 1998; 13: 1668-1674

27. Lehrke I, Waldherr R, Ritz E et al. Renal endothelin-1 and endothelin receptor type B expression in glomerular diseases with proteinuria. J Am Soc Nephrol 2001; 12: 2321-2329

28. Ohta K, Hirata $\mathrm{Y}$, Shichiri $\mathrm{M}$ et al. Urinary excretion of endothelin-1 in normal subjects and patients with renal disease. Kidney Int 1991; 39: 307-311

29. Dhaun N, Lilitkarntakul P, Macintyre IM et al. Urinary endothelin-1 in chronic kidney disease and as a marker of disease activity in lupus nephritis. Am J Physiol Renal Physiol 2009; 296: F1477-F1483

30. Iwasa S, Fan J, Shimokama $T$ et al. Increased immunoreactivity of endothelin-1 and endothelin B receptor in human atherosclerotic lesions. A possible role in atherogenesis. Atherosclerosis 1999; 146: 93-100

31. Bacon CR, Cary NR, Davenport AP. Endothelin peptide and receptors in human atherosclerotic coronary artery and aorta. Circ Res 1996; 79: 794-801

32. Ortmann J, Amann K, Brandes RP et al. Role of podocytes for reversal of glomerulosclerosis and proteinuria in the aging kidney after endothelin inhibition. Hypertension 2004; 44: 974-981

33. Benigni A, Zoja C, Corna D et al. A specific endothelin subtype A receptor antagonist protects against injury in renal disease progression. Kidney Int 1993; 44: 440-444
34. Benigni A, Zola C, Corna D et al. Blocking both type A and B endothelin receptors in the kidney attenuates renal injury and prolongs survival in rats with remnant kidney. Am J Kidney Dis 1996; 27: 416-423

35. Nakamura T, Ebihara I, Fukui $M$ et al. Effect of a specific endothelin receptor A antagonist on mRNA levels for extracellular matrix components and growth factors in diabetic glomeruli. Diabetes 1995; 44: 895-899

36. Sasser JM, Sullivan JC, Hobbs JL et al. Endothelin A receptor blockade reduces diabetic renal injury via an anti-inflammatory mechanism. J Am Soc Nephrol 2007; 18: 143-154

37. Saleh MA, Pollock JS, Pollock DM. Distinct actions of endothelin A-selective versus combined endothelin $\mathrm{A} / \mathrm{B}$ receptor antagonists in early diabetic kidney disease. J Pharmacol Exp Ther 2011; 338: 263-270

38. Gagliardini E, Corna D, Zoja C et al. Unlike each drug alone, lisinopril if combined with avosentan promotes regression of renal lesions in experimental diabetes. Am J Physiol Renal Physiol 2009; 297: F1448-F1456

39. Barton M, Haudenschild CC, d'Uscio LV et al. Endothelin ETA receptor blockade restores NO-mediated endothelial function and inhibits atherosclerosis in apolipoprotein E-deficient mice. Proc Natl Acad Sci USA 1998; 95: 14367-14372

40. Bussemaker E, Passauer J, Reimann D et al. The vascular endothelin system is not overactive in normotensive hemodialysis patients. Kidney Int 2002; 62: 940-948

41. Hand MF, Haynes WG, Webb DJ. Reduced endogenous endothelin-1mediated vascular tone in chronic renal failure. Kidney Int 1999; 55: 613-620

42. Goddard J, Johnston NR, Hand MF et al. Endothelin-A receptor antagonism reduces blood pressure and increases renal blood flow in hypertensive patients with chronic renal failure: a comparison of selective and combined endothelin receptor blockade. Circulation 2004; 109: $1186-1193$

43. Goddard J, Eckhart C, Johnston NR et al. Endothelin A receptor antagonism and angiotensin-converting enzyme inhibition are synergistic via an endothelin B receptor-mediated and nitric oxide-dependent mechanism. J Am Soc Nephrol 2004; 15: 2601-2610

44. Dhaun N, Macintyre IM, Melville V et al. Blood pressure-independent reduction in proteinuria and arterial stiffness after acute endothelin-a receptor antagonism in chronic kidney disease. Hypertension 2009; 54: 113-119

45. Dhaun N, MacIntyre IM, Kerr D et al. Selective endothelin-A receptor antagonism reduces proteinuria, blood pressure, and arterial stiffness in chronic proteinuric kidney disease. Hypertension 2011; 57: 772-779

46. Humbert M, Segal ES, Kiely DG et al. Results of European post-marketing surveillance of bosentan in pulmonary hypertension. Eur Respir J 2007; 30: $338-344$

47. Hartman JC, Brouwer K, Mandagere A et al. Evaluation of the endothelin receptor antagonists ambrisentan, darusentan, bosentan, and sitaxsentan as substrates and inhibitors of hepatobiliary transporters in sandwichcultured human hepatocytes. Can J Physiol Pharmacol 2010; 88: 682-691

48. Wenzel RR, Littke T, Kuranoff $\mathrm{S}$ et al. Avosentan reduces albumin excretion in diabetics with macroalbuminuria. J Am Soc Nephrol 2009; 20: 655-664

49. Mann JF, Green D, Jamerson K et al. Avosentan for overt diabetic nephropathy. J Am Soc Nephrol 2010; 21: 527-535

50. Black HR, Bakris GL, Weber MA et al. Efficacy and safety of darusentan in patients with resistant hypertension: results from a randomized, doubleblind, placebo-controlled dose-ranging study. J Clin Hypertens (Greenwich) 2007; 9: 760-769

51. Kohan DE, Pritchett Y, Molitch M et al. Addition of atrasentan to reninangiotensin system blockade reduces albuminuria in diabetic nephropathy. J Am Soc Nephrol 2011; 22: 763-772

52. Cross DM, Horsley E, Derzi M et al. An evaluation of reproductive and developmental toxicity of sitaxentan (thelin) in rats. Birth Defects Res B Dev Reprod Toxicol 2012; 95: 327-336

Received for publication: 8.4.2013; Accepted in revised form: 8.7.2013 